\title{
A cost-effective cadaveric model for plastic surgery simulation
}

\author{
Sir, \\ The hours plastic surgery trainees spend in the operating \\ theatre are increasingly limited compared to their \\ predecessors due to current working time regulations, \\ especially in Europe. ${ }^{[1]}$ Trainees have to look for alternative \\ training methods to hone their skills, and cadaveric \\ models can be the answer in complementing regular \\ surgical training. A recent systematic review concluded \\ that training using a cadaveric model is a good way to \\ increase trainees' confidence. ${ }^{[2]}$ Fresh frozen cadavers \\ are the gold standard in providing a realistic simulation \\ of live surgery. Unfortunately, without costly freezer \\ storage, they decompose quickly after defrosting. \\ Traditionally, formalin was used to embalm bodies for the \\ study of anatomy. However, tissue changes induced by \\ formalin make it a poor substitute for the use of plastic \\ surgery simulation. Fortunately, advances in embalming \\ methods introduced soft-fixation techniques, such as \\ Thiel and Genelyn, which gave cadavers live-like tissue \\ quality such as softness and flexibility. An earlier study by \\ Jaung had confirmed the superiority of Thiel over other \\ embalming techniques, including Genelyn, in producing \\ live-like cadavers for surgical training. ${ }^{|3|}$ However, \\ centres should take a few other factors, such as cost
}


and production time, into consideration when deciding which technique is most suitable for them. First, with regards to production time, Thiel cadavers have to be immersed for a minimum of 3 months. ${ }^{[1]}$ Second, the Thiel method requires investment in expensive new facilities. ${ }^{[4]}$

The Genelyn cadaveric model is overall a cheap, good and convenient alternative in the practice of raising microvascular flaps. Genelyn's exact composition is unknown as it is a propriety mix, but it contains methanol, formaldehyde and dyes. The embalming procedure involves getting arterial access via the femoral or carotid arteries and draining the fluid from the femoral or jugular veins. The advantages of Genelyn are that it does not require expensive investment in any new infrastructure, and its production is significantly faster because cadavers do not need to be immersed for long periods.

As a soft fix embalming technique, Genelyncadavers exhibit relatively good tissue pliability and joint mobility. This is confirmed when we compared the range of movements of various joints between Genelyn and formalin cadavers. In all joints evaluated, Genelyn cadavers exhibit a greater range of movement compared to formalin cadavers. This is especially useful for simulating real surgical conditions as patients may have to be placed in different positions for surgical procedures [Figure 1].

We also attempted a pilot study in comparing between Genelyn and formalin cadavers in raising microvascular flaps. One formalin and one Genelyn cadaver were used. A trainee was recruited to raise a dorsalis pedis flap on both models and had to fill in a questionnaire to rate the surgical experience upon completion (1-10, 1 being unsuitable for simulation and 10 being as

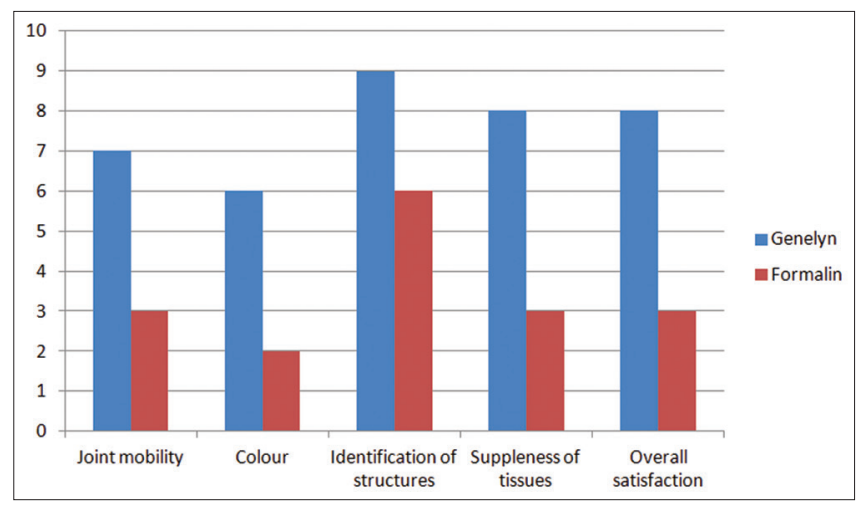

Figure 1: Comparison of the surgical experience of Genelyn and Formalin cadavers good as live surgery). The Genelyn model scored highly on all aspects including the ease of identification of structures, suppleness, colour of the tissues and overall satisfaction. The time taken to complete the procedure was also significantly shorter in the Genelyn model [Figure 1].

In conclusion, although Thiel cadavers currently provide the best surgical simulation among the soft fix embalming methods, the above authors believe that the Genelyn cadaveric model is sufficiently good for plastic surgery simulation and is much more cost-effective after taking into consideration the logistical requirements. ${ }^{[4]}$ Plastic surgery trainees can benefit from more practice on the Genelyn cadaveric model, and in the future, more studies into other plastic surgery techniques that could be simulated on this model should be investigated.

\section{Financial support and sponsorship}

Nil.

\section{Conflicts of interest}

There are no conflicts of interest.

\section{Nigel Yong Boon Ng, Charles Yuen Yung Loh', Thanassi Athanassopoulos ${ }^{2}$}

Department of Surgery, Glasgow Royal Infirmary, Glasgow, Scotland, 'Department of Plastic Surgery, Broomfield Hospital, Chelmsford, United Kingdom, ${ }^{2}$ National Burns Centre, Middlemore Hospital, Auckland, New Zealand

Address for correspondence: Dr. Nigel Yong Boon Ng, Department of Surgery, Glasgow Royal Infirmary, Glasgow, Scotland, United Kingdom. E-mail: nigelybng@gmail.com

\section{REFERENCES}

1. Dean B, Pereira E. Surgeons and training time. London: BMJ Careers; 2011. URL: http://careers.bmj.com/careers/advice/ view-article.html?id=20005162 [Last cited on 2014 Aug 14].

2. Gilbody J, Prasthofer AW, Ho K, Costa ML. The use and effectiveness of cadaveric workshops in higher surgical training: A systematic review. Ann R Coll Surg Engl 2011;93:347-52.

3. Jaung $R$, Cook P, Blyth P. A comparison of embalming fluids for use in surgical workshops. Clin Anat 2011;24:155-61.

4. Hammer N, Löffler S, Bechmann I, Steinke H, Hädrich C, Feja C. Comparison of modified Thiel embalming and ethanol-glycerin fixation in an anatomy environment: Potentials and limitations of two complementary techniques. Anat Sci Educ 2015;8:74-85.

This is an open access article distributed under the terms of the Creative Commons Attribution-NonCommercial-ShareAlike 3.0 License, which allows others to remix, tweak, and build upon the work non-commercially, as long as the author is credited and the new creations are licensed under the identical terms. 


\begin{tabular}{|l|l|}
\hline \multicolumn{2}{|c|}{ Access this article online } \\
\hline Quick Response Code: & Website: \\
\hline & www.ijps.org \\
\cline { 2 - 2 } & DOI: \\
\hline
\end{tabular}

How to cite this article: Ng NY, Loh CY, Athanassopoulos T. A cost-effective cadaveric model for plastic surgery simulation. Indian J Plast Surg 2016;49:121-3. 